\title{
異なる肩関節屈曲角度の運動方向での上肢の 複合運動時筋力と基本動作との関係
}

\section{Relationship between Muscle Strength during Closed Kinetic Chain Exercise Using Upper Extremities at Different Flexion Angles of the Shoulder Joint and Basic Activities}

\author{
千葉 直美1) 半澤 宏美 ${ }^{2)}$ 佐々木 誠3)
}

NAOMI CHIBA, RPT ${ }^{1)}$, HirOMI HANAZAWA, RPT ${ }^{2)}$, MAKOTO SASAKI, RPT, PhD ${ }^{3)}$

${ }^{1)}$ Department of Rehabilitation, Sendai City National Hospital: 2-8-8 Miyagino, Miyagino-ku, Sendai, Miyagi 983-8520, Japan. TEL + 81 022-293-1180

${ }^{2)}$ Department of Rehabilitation, Naruko Public Hospital

${ }^{3)}$ Department of Physical Therapy, School of Health Science, Faculty of Medicine, Akita University

Rigakuryoho Kagaku 19(1): 43-48, 2003. Submitted Jun. 26, 2002. Accepted Nov. 4, 2003.

\begin{abstract}
The purposes of this study were to compare muscle strengths during closed kinetic chain (CKC) exercise using upper limbs at different flexion angles of the shoulder joint, and to clarify the relationship between these muscle strengths and basic activities. Fourteen healthy women aged 19.1 \pm 1.2 years (mean \pm SD) participated in this study. The extensor muscle strengths during CKC exercise using upper extremity were measured under twelve conditions combining each shoulder flexion angle of 0,30,60 and 90 degrees with velocities of 60,180 and 300 degree/sec. The three basic activities, wheelchair driving time on a $10 \mathrm{~m}$ path, the number of push-ups performed in 30 seconds, and the ratio of weight bearing relieved by loading on a T-cane to body weight, were measured under subjects' maximum effort. The muscle strengths (peak torque/body weight) during CKC exercise using the upper extremity did not show significant differences among shoulder flexion angles at all exercise velocities. Peak torque/body weight in all movement directions at 300 degree/sec tended to relate inversely to the wheelchair driving time, whereas there was no significant relationship between muscle strengths and the number of push-ups. In addition, peak torque/body weight in all exercise directions at 60 degree/sec tended to correlate with the ratio of weight bearing relieved by loading on a Tcane. In particular, there was a significant relationship between peak torque/bodyweight in shoulder flexion angle of 30 degrees at 60 degree/sec and the ratio of weight bearing relieved by loading on a T-cane. These results suggest that there is no exercise direction specificity, even though muscle strengths of CKC exercise using upper extremity at different flexion angles of the shoulder joint should reflect participation of various muscles and different contractile recruitment ratios. In addition, wheelchair driving time on a $10 \mathrm{~m}$ path may be influenced by velocity specificity but not by difference of motion direction, and the ratio of weight bearing relieved by loading on a T-cane may reflect specificities in both velocity and exercise direction of muscle strengths.
\end{abstract}

Key words: closed kinetic chain, upper extremity, basic activities

要旨：異なる肩関節屈曲角度での上肢クローズドキネティックチェイン（CKC）運動時筋力を測定し，運動方向によ る差異を比較するとともに，基本動作との関連を検討した。対象は若年健常女性14名（19.1 1 1.2歳）である。方法と して，まず肩関節屈曲 $0^{\circ} ， 30^{\circ} ， 60^{\circ} ， 90^{\circ}$ 方向への上肢CKCでの伸展運動時等速性筋力を，60， $180 ， 300 \mathrm{deg} / \mathrm{sec}$ の運動速度で測定した。また，車椅子 $10 \mathrm{~m}$ 駆動時間，30秒間に反復可能なプッシュアップ回数， $\mathrm{T}$ 字杖免荷率の3項 目を測定した。各肩関節屈曲角度における上肢CKC運動時のPeak Torque/Body Weightは，全ての運動速度において差

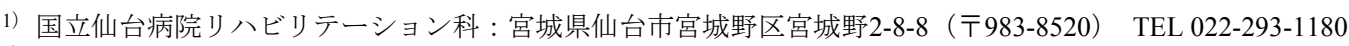

2) 町立鳴子温泉病院リハビリテーション室

3) 秋田大学医学部保健学科理学療法学専攻

受付日 2002年6月26日受理日 2003年11月4日 
異を認めなかった。筋力と基本動作との関係について, Peak Torque/Body Weightは, プッシュアップ回数との間に相関が示

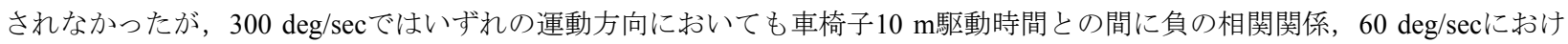
る全ての運動方向で $\mathrm{T}$ 字杖免荷率との間に関連があることが示唆された。また， $\mathrm{T}$ 字杖免荷率と低角速度での肩関節屈曲 $30^{\circ}$ 方向におけるPeak Torque/Body Weightとの間の相関関係は統計学的に有意であった。以上より，異なる肩関節屈曲角度にお ける上肢CKC運動時筋力は，運動方向によって関与する筋の種類や活動動員比率が異なると推察されるものの，運動方向特 異性は示されなかった。また, 車椅子 $10 \mathrm{~m}$ 駆動時間は, $\mathrm{CKC}$ 運動時筋力の角速度特異性が反映される一方で, 運動方向の相 違には影響されず, $\mathrm{T}$ 字杖免荷率は, 筋力の角速度特異性ならびに運動方向特異性に影響されることが示唆された。

キーワード : クローズドキネティックチェイン, 上肢, 基本動作

\section{I. はじめに}

我々はこれまでクローズドキネティックチェイン（以 下， CKC）での上肢等速性運動時筋力の再現性を検討し, また, 肘関節伸展筋力のみでは上肢CKC筋力を十分には 説明し得ないことを示してきた1)。肢体不自由者では, 車 椅子駆動やプッシュアップ移動, 杖での体重支持などの 必要性が増す症例が少なくなく, 上肢の単一筋に関する 知見に加えて上肢帯ならびに上肢の複合的な $\mathrm{CKC}$ 運動に おける筋力の検討が重要であると考える。上肢CKC運動 の際の運動方向が異なると, 動員される筋の比率が変化 するため, 出力としての筋力も変化するものと推測され る。また, 運動方向特性が上肢を使用した起居移動動作 能力に反映するものと考えられる。このような見地から， 我々は異なる肩関節外転角度における上肢 $\mathrm{CKC}$ 運動時筋 力と基本動作との関係について報告した ${ }^{2)}$ 。そこでは, 運 動速度にかかわらず肩関節が外転するにしたがって上肢 $\mathrm{CKC}$ 運動時筋力が低值となること, ならびにこの筋力が T字杖を用いて免荷できる比率と関連することを見出し た2)。

今回は, 運動方向を肩関節外転角度ではなく屈曲角度 で規定し，同様の検討をすることで更なる知見を得るこ とを目的とした。そこで, 異なる肩関節屈曲角度での上 肢におけるCKC運動時筋力を測定し, 運動方向による差 異を比較するとともに，基本動作との関連を検討した。

\section{II. 対象と方法}

対象は若年健常女性14名であり, その年齢, 身長, 体 重, BMIの平均は, それぞれ $19.1 \pm 1.2$ 歳, $158.2 \pm 3.9 \mathrm{~cm}$, $55.5 \pm 7.8 \mathrm{~kg}, 22.1 \pm 2.7 \mathrm{~kg} / \mathrm{m}^{2}$ であった。なお，研究に関 して文書ならびに口頭で説明を行い, 同意が得られた場 合には対象者に同意書に署名してもらった。

筋力測定には等速性筋力測定器BIODEX SYSTEM 2AP を， closed chain attachmentを装備して用いた。なお，本 attachmentの構造については, 佐々木ら ${ }^{3,4)}$ が詳細に説明し
ている。測定肢位は測定器のシート上での坐位とし，シー 卜背もたれの調整にて肩関節屈曲角度をそれぞれ設定し た。運動方向は肩関節外転 $0^{\circ}$ での肩関節屈曲 $0^{\circ}, 30^{\circ}$, $60^{\circ}, 90^{\circ}$ とした。パワーヘッド軸を肩峰に合わせ, closed chain attachmentのロードセルバーを前腕回内外中間位で 把持させた。身体の固定は，肩関節屈曲 $30^{\circ} ， 60^{\circ}, 90^{\circ}$ の運動方向では備え付けのベルトを使用して行った。肩 関節屈曲 $0^{\circ}$ の運動方向ではシート背もたれが水平位, 被 検者は背臥位となりベルトでの固定力が保証されないた め, シート端に膝窩部を位置させて下腿を下垂させ，更 に一人の検者が頭部側より両肩を徒手的に固定した。肩 関節屈曲 $30^{\circ}$ の運動方向での測定風景を図 1 に例示した。 運動速度は低速, 中速, 高速のそれぞれの代表として60 $\mathrm{deg} / \mathrm{sec}, 180 \mathrm{deg} / \mathrm{sec}, 300 \mathrm{deg} / \mathrm{sec}$ とし5), 左右上肢の運動 を別々に測定した。測定の際は最大限に筋力を発揮する ように，同一検者が声掛けした状況下で，対象者に上肢 全体を伸展屈曲させた。左右上肢, 運動方向, 運動速度 の順序はランダム化し，各測定間には60秒程度の休憩を 入れた。測定パラメータは伸展運動方向のPeak Torque/ Body Weightを採用し, 各測定5回反復の最大值の左右の 平均值を代表值とした。

また，このCKC運動時筋力と基本動作能力の関連をみ るために測定した動作は, 車椅子駆動, プッシュアップ, 片側でT字杖を使用しての立位保持の3項目である。車椅 子駆動の能力の測定には, OG技研社製ユニバーサル型車 椅子RG-20を使用し, 対象者にはこの車椅子を最大速度 で駆動するよう求めた。スタートラインとゴールライン の間に $10 \mathrm{~m}$ の距離をとり, 約 $3 \mathrm{~m}$ の助走距離を駆動した後 の直線コースの駆動時間を測定した（以下，車椅子 $10 \mathrm{~m}$ 駆動時間)。プッシュアップは, 診療用ベッド上で足底接 地を行わないよう端坐位をとり, OG技研社製プッシュ アップ台GH-381（中）（高さ；18.0 cm）を対象者の使用 しやすい位置に設定した。坐面に殿部が接地している肘 関節屈曲位から肘関節完全伸展位に至るまでを1回とし, 30 秒間に可能なだけのプッシュアップ反復回数を測定し た（以下，プッシュアップ回数）。 $\mathrm{T}$ 字杖を使用しての立 


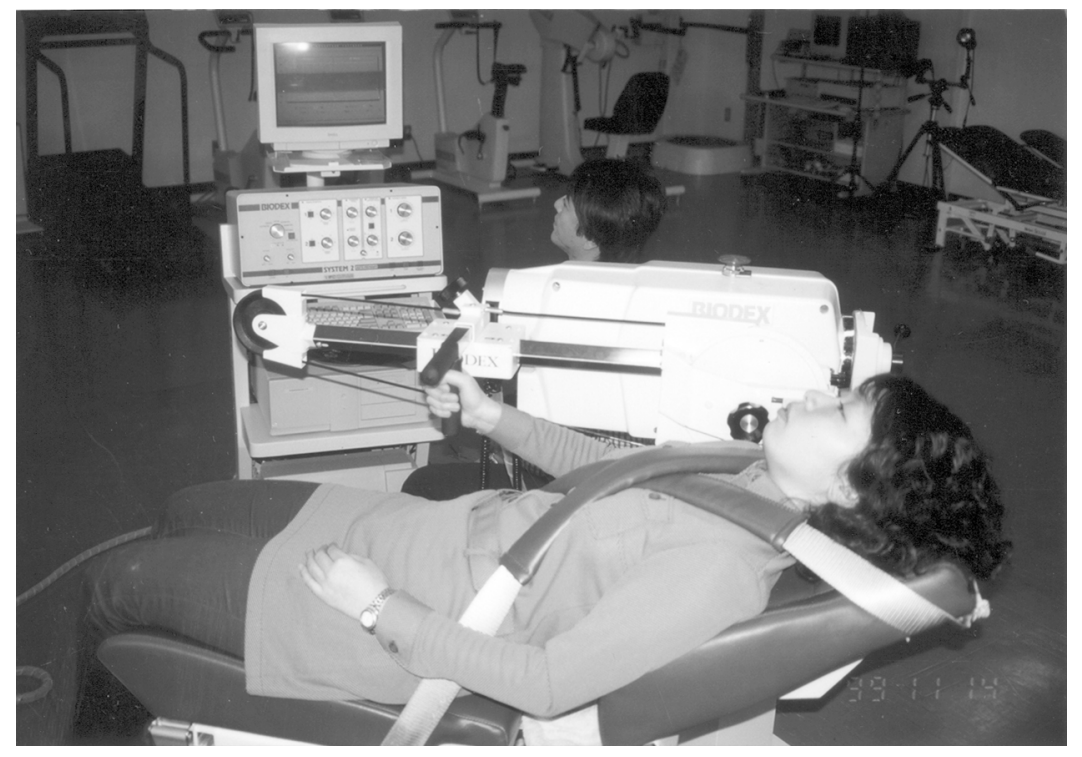

図1 測定風景

表1 上肢CKC運動時伸展Peak Torque/Body Weightの運動方向による比較

\begin{tabular}{lccccc}
\hline & \multicolumn{3}{c}{ 運動方向 } \\
& $0^{\circ}$ & $30^{\circ}$ & $\begin{array}{c}\text { (肩関節屈曲角度) } \\
60^{\circ}\end{array}$ & $90^{\circ}$ & $\begin{array}{c}\text { 有意性 } \\
\text { (ANOVA) }\end{array}$ \\
\hline 運動角速度 & & & & & \\
$60 \mathrm{deg} / \mathrm{sec}$ & $56.1 \pm 16.8$ & $56.8 \pm 15.5$ & $53.2 \pm 18.7$ & $55.1 \pm 16.9$ & N.S. \\
$180 \mathrm{deg} / \mathrm{sec}$ & $34.6 \pm 17.2$ & $32.8 \pm 15.0$ & $33.6 \pm 15.3$ & $32.6 \pm 10.1$ & N.S. \\
$300 \mathrm{deg} / \mathrm{sec}$ & $24.4 \pm 9.9$ & $25.2 \pm 9.8$ & $23.8 \pm 8.4$ & $23.2 \pm 8.2$ & N.S. \\
\hline
\end{tabular}

平均土標準偏差，単位：\%, N.S. : not significant

位保持では, 杖の長さを一般に推奨されている方法で握 りの部分が大転子にくるように調節6)した。採寸方法と同 様に杖把持側の足趾より $15 \mathrm{~cm}$ 外側・前方に杖先を位置さ せた。対象者が乗った体重計と同じ高さの台の上に設地 した片側T字杖一最大限に荷重した際に免荷された重量 を測定し\%比率で表した。その免荷率を左右測定して平 均し代表值とした（以下， $\mathrm{T}$ 字杖免荷率）。

統計学的手法に関して, 異なる3 種の肩関節屈曲角度に おける筋力の比較には反復測定分散分析を, 各CKC筋力 と各起居移動動作能力との間の関連の検討にはPearsonの 相関関係の検定を用いた。なお，危険率 $5 \%$ 未満をもって 有意とした。

\section{III. 結 果}

まず，全ての運動速度において肩関節屈曲角度におけ るPeak Torque/Body Weight（表1）は，運動方向による差 異を認めなかった。

次に, 基本動作能力の測定值を表 2 に示した。車椅子 10 $\mathrm{m}$ 駆動時間の平均は $5.5 \pm 0.6 \mathrm{sec}$, プッシュアップ回数の 平均は20.6 \pm 9.4 回, $\mathrm{T}$ 字杖免荷率の平均は $29.5 \pm 11.2 \%$ で あつた。

最後に, 筋力と基本動作能力との関連について表3に示 した。Peak Torque/Body Weight と起居移動動作能力との関 係をみると，車椅子 $10 \mathrm{~m}$ 駆動時間との間には, $300 \mathrm{deg} / \mathrm{sec}$ において, 屈曲 $0^{\circ}$ 方向で $\mathrm{r}=-0.663(\mathrm{p}<0.05)$, 屈曲 $90^{\circ}$ 方向で $\mathrm{r}=-0.657 \quad(\mathrm{p}<0.05)$ の有意な相関を認めた。また, 屈曲 $30^{\circ}$ 方向で $\mathrm{r}=-0.525(\mathrm{p}=0.0798)$, 屈曲 $60^{\circ}$ 方向で 
表2 基本動作能力の測定値

\begin{tabular}{lcc}
\hline & 平均值士標淮偏差 & 範囲 \\
\hline 車椅子 $10 \mathrm{~m}$ 駆動時間 $(\mathrm{sec})$ & $5.5 \pm 0.6$ & $4.5-6.5$ \\
プッシュアップ回数（回） & $20.6 \pm 9.4$ & $12-37$ \\
$\mathrm{~T}$ 字杖免荷率 $(\%)$ & $29.5 \pm 11.2$ & $5.9-41.9$ \\
\hline
\end{tabular}

表3 上肢 $\mathrm{CKC}$ 運動時伸展Peak Torque/Body Weight と基本動作能力との相関係数（r)

\begin{tabular}{|c|c|c|c|c|}
\hline & & 車椅子 10 m 駆動時間 & $\begin{array}{l}\text { 起居移動動作能力 } \\
\text { プッシュアップ回数 }\end{array}$ & $\mathrm{T}$ 字杖免荷率 \\
\hline \multicolumn{5}{|l|}{ 運動方向角速度 } \\
\hline \multirow[t]{3}{*}{ 肩関節屈曲 $0^{\circ}$} & $60 \mathrm{deg} / \mathrm{sec}$ & -0.346 & 0.277 & 0.526 \\
\hline & $180 \mathrm{deg} / \mathrm{sec}$ & -0.320 & 0.241 & 0.444 \\
\hline & $300 \mathrm{deg} / \mathrm{sec}$ & $-0.663^{*}$ & 0.291 & 0.421 \\
\hline \multirow[t]{3}{*}{ 肩関節屈曲 $30^{\circ}$} & $60 \mathrm{deg} / \mathrm{sec}$ & -0.416 & 0.194 & $0.547 *$ \\
\hline & $180 \mathrm{deg} / \mathrm{sec}$ & -0.321 & 0.062 & 0.444 \\
\hline & $300 \mathrm{deg} / \mathrm{sec}$ & -0.525 & 0.068 & 0.301 \\
\hline \multirow[t]{3}{*}{ 肩関節屈曲 $60^{\circ}$} & $60 \mathrm{deg} / \mathrm{sec}$ & -0.429 & 0.274 & 0.521 \\
\hline & $180 \mathrm{deg} / \mathrm{sec}$ & -0.438 & 0.210 & 0.475 \\
\hline & $300 \mathrm{deg} / \mathrm{sec}$ & -0.565 & -0.044 & 0.460 \\
\hline \multirow[t]{3}{*}{ 肩関節屈曲 $90^{\circ}$} & $60 \mathrm{deg} / \mathrm{sec}$ & -0.460 & 0.280 & 0.541 \\
\hline & $180 \mathrm{deg} / \mathrm{sec}$ & -0.272 & 0.187 & 0.468 \\
\hline & $300 \mathrm{deg} / \mathrm{sec}$ & $-0.657 *$ & 0.031 & 0.440 \\
\hline
\end{tabular}

*: $\mathrm{p}<0.05$

$\mathrm{r}=-0.565(\mathrm{p}=0.0702)$ の相関のある傾向が示された。一 方, プッシュアップ回数との間には関連を認めなかった。 またT字杖免荷率との間には, $60 \mathrm{deg} / \mathrm{sec}$ におて, 屈曲 $30^{\circ}$ 方向で $\mathrm{r}=0.547 \quad(\mathrm{p}<0.05)$ の有意な相関が示され, 屈 曲 $0^{\circ}$ 方向で $\mathrm{r}=0.526 \quad(\mathrm{p}=0.0651)$, 屈曲 $60^{\circ}$ 方向で $\mathrm{r}=0.521$ $(\mathrm{p}=0.0679)$, 屈曲 $90^{\circ}$ 方向で $\mathrm{r}=0.541 （ \mathrm{p}=0.0693 ）$ の相関 のある傾向を認めた。

\section{IV. 考 察}

まず第一に，上肢のCKC運動時筋力を測定した結果， いずれの運動速度においてもPeak Torque/Body Weightは, 肩関節屈曲角度を変えても差異がないことが示された。 これは, 我々の以前の研究2)で報告したような, 肩関節の 外転角度が増すにつれて, 上肢CKC運動時筋力が減じる という運動方向特異性を示した結果とは異なるものであ る。我々の別の研究1)では, 上肢のCKC運動時筋力と肘関 節伸展筋力との間には十分な相関を認めなかった。また
同検討1)で，肩関節屈曲 $0^{\circ}$ 方向へのCKC運動時筋力に対 する肘関節伸展筋力が，屈曲 $90^{\circ}$ 方向へのCKC運動時筋 力に対する肘関節伸展筋力に比較して, いずれの運動速 度でも有意に小さいことを報告した。すなわち，上肢の $\mathrm{CKC}$ 運動時筋力に寄与寸る筋として肩甲帯関与筋や手関 節の固定筋が重要であり，運動方向を肩関節屈曲 $90^{\circ}$ 方 向から屈曲 $0^{\circ}$ 方向へと変化させていった場合, これらの 筋の関与する重要性が増すことが考えられる。本研究に おいて，手関節の固定筋が運動方向によって大きくは影 響を受けないとすると, 運動方向が肩関節屈曲 $90^{\circ}$ 方向 から屈曲 $0^{\circ}$ 方向へと移行するにしたがって, 肩甲骨外転 作用を有する前鋸筋, 上腕骨水平内転作用を有する大胸 筋や三角筋前部線維, 上腕骨内転作用を有寸る烏口腕筋 などの筋6,7)から肩甲骨下制作用を有する僧帽筋下部線 維, 上腕骨内転作用を有する大胸筋, 広背筋, 大円筋, 烏口腕筋などの筋7,8)へと, 各筋の活動動員量を変えつつ 寄与する筋の種類が変化していたものと推察される。し かし, 时関節伸展筋や肩甲帯関与筋, 手関節の固定筋を 
含む上肢全体のCKC運動時に発揮される筋力としてみた 場合には，結果的に差異を認めなかったものと考える。 肩関節の外転角度を变えて行った実験2)では, 広背筋が結 果に影響する主な作用筋であると考え, 外転角度が増す のに伴なって, この筋の身体尾部方向に押寸作用に対寸 る上腕骨を内転させる作用が相対的に増加するため, 運 動方向特異性が示されたと解釈した。これと異なり, 本 研究結果は複数の筋の複雑な作用の総和の変化があり, 運動方向特異性が示されなかったものと考える。

第二に, 筋力と基本動作能力との関連について, Peak Torque/Body Weight は, $300 \mathrm{deg} / \mathrm{sec} の$ 角速度でいずれの運 動方向においても，車椅子 10 m駆動時間との間に負の有 意な相関あるいは相関がある傾向が示された。 $300 \mathrm{deg} / \mathrm{sec}$ はCKCの直線運動に換算すると約 $60 \mathrm{~cm} / \mathrm{sec}$ を意味してい る。計算により課題遂行時の車椅子ハンドリムの平均回 転軌跡速度が $170 \mathrm{~cm} / \mathrm{sec}$ 超えることから，今回測定し た種類の角速度の中でこの平均回転軌跡速度に最も近い ために, $300 \mathrm{deg} / \mathrm{sec}$ 角速度においてのみ相関関係が示 唆されたものと考える。春髄損傷患者における車椅子駆 動時の動作解析では, 上腕骨は肩甲上腕関節の中心を軸 として後方 $57.3^{\circ}$ から前方 $23.2^{\circ}$ までの可動範囲を有す る9)ことが示されている。また, ハンドリムに接触してい る回転弧範囲が，車椅子非使用者では車椅子使用者より も狭い10)ことが報告されている。本研究の対象者は日常 的に車椅子移動を行っている者ではなく, 車椅子駆動時 の上腕骨の可動範囲はより限られていたと推察される。 しかし, 車椅子非使用者は使用者に比べて, ハンドリム への力を車軸方向よりもリムの接線方向へ作用させ，か つ, この方向への力の作用を短時間, 強く働かせる10)こ とが示されている。すなわち, 局関節の限られた屈曲運 動方向よりも, 力学的には更に前方へ力の作用を速く, 強く発揮させていた可能性があり, 肩関節屈曲方向が 0 。 のみならず $90^{\circ}$ のCKC運動時筋力においても, 駆動時間 との間に関連が示唆されたものと考える。

今回認められた車椅子駆動時間の運動速度特異性は, 肩関節を外転させたCKC運動時筋力の実験 2 では示され ていない。 Boningerら ${ }^{11)}$ は, 車椅子駆動のハンドリムプッ シュ相において肩関節が伸展位から屈曲していく際に, 肩関節は外転位から内転方向へと, 肘関節は屈曲位から 更に屈曲した後伸展方向へと, 運動推移することを報告 している。この相での作用筋として, 相の前半では大胸 筋や三角筋前部線維が, 後半では上腕三頭筋や三角筋後 部線維が主に作用する ${ }^{12)}$ 。肩関節を外転させた場合には， 広背筋による肩関節内転作用の優位性が車椅子駆動には 反映されにくい2)のに対して, 本研究で肩関節の屈曲角度
を設定した場合には，前述した筋のうちの少なくとも大 胸筋や三角筋前部線維といった水平内転作用を有寸る筋 の影響があったため, 運動速度特異性を認めたものと考 える。

プッシュアップ回数はPeak Torque/Body Weight との間 に相関が認められなかった。これは肩関節の外転角度を 変化させた研究2) と同一の結果であった。この動作は上肢 CKC運動による求心性, 遠心性運動の反復動作であり, 上肢帯の安定性を得るための筋力に加えて持久力が求め られる。Peak Torque/Body Weightは筋の瞬発力を反映し やすいため, これが関連性を見出せなかった理由の一つ であると考える。また, 物を押寸際のその客体が可動自 由度を有していると, 客体が固定されている時に比べて, 客体に加わる力が低值であり, 三角筋前部線維や上腕三 頭筋の筋電活動が減少し, 手関節屈筋・伸筋の活動が増 加する13)ことが示されている。本研究では, プッシュアッ プ台を坐面に固定しなかったため, プッシュアップ台の 不安定性が筋力測定時とは異なる筋活動が求められてい た可能性がある。

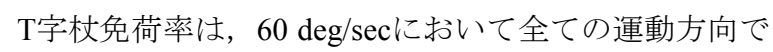
のPeak Torque/Body Weight との間に正の有意な相関ある いは相関がある傾向を認めた。この運動速度特異性は, 運動方向を肩関節外転方向で設定した研究2) と同様の結 果であった。この課題は筋の等尺性収縮を求めるもので あり, 角速度の遅い条件での筋力との関連が示されたも のと考える。本測定では, 杖で支持する際に杖先の床と の接点を支持側足部より $15 \mathrm{~cm}$ 外側・前方に設定したこと により肩関節が軽度屈曲位となり, 外転方向に運動方向 を変化させた実験2)での結果と異なって, 相関関係は肩関 節屈曲 $30^{\circ}$ 方向で特に統計学的にも有意であり, 運動方 向特異性が示されたものと考える。

以上より今回の研究では, 4 種類の肩関節屈曲角度の運 動方向において, 関与寸る筋の種類や活動動員比率が異 なると推察されるものの, 運動方向特異性は示されな かった。また, 筋力と基本動作との関係については, プッ シュアップ回数では相関を示し得なかったが，車椅子 10 m駆動時間は, 高角速度でのPeak Torque/Body Weight との 間にいずれの運動方向においても相関関係が示唆され, T 字杖免荷率は, 低角速度において全ての運動方向での Peak Torque/Body Weightとの間に関連性が示唆された。特 に, $\mathrm{T}$ 字杖免荷率と低角速度での肩関節屈曲 $30^{\circ}$ 方向に おけるPeak Torque/Body Weight との間の相関関係は統計 学的に有意であり, T字杖免荷率においては, 角速度特異 性に加えて運動方向特異性が示唆された。 


\section{文 献}

1) 佐々木誠, 千葉直美, 半澤宏美: 上肢クローズド・キネティッ ク・チェインでの等速性筋力の測定再現性および等速性肘関 節伸展筋力との関連. 東北理学療法学, 2001, 12:24-29.

2) 佐々木誠, 山上弘義, 白鳥常男 : 等速性片側脚伸展筋力測定 の再現性および等速性膝伸展筋力との関係. 理学療法学, 1998, 25(2) : 67-71.

3) 半澤宏美, 千葉直美, 佐々木誠 : 異なる肩関節外転角度にお ける上肢の複合運動時筋力と起居移動動作との関係. 理学療 法科学, 2002, 17(4) : 227-232.

4) 佐々木誠, 山上弘義, 白鳥常男: 等速性脚伸展筋力増強訓練 と等速性膝伸展筋力増強訓練とのトレーニング効果の比較. PTジャーナル, 1998, 32(5) : 367-372.

5) 川島敏生, 三ッ木豊, 川島昭彦・他 : クローズドキネティッ クチェインとの関連からみた等速性筋力評価における測定 速度の検討. 理学療法学, 1993, 20(1) : 14-18.

6) 額谷一夫 : 日常生活活動 移動補助具. 黒川幸雄 - 他編, 臨 床理学療法マニュアル, 南江堂, 東京, 1996, pp215-230.

7) Hislop HJ, Montgomery J: Danies and Worthingham's MUSCLE
TESTING; Techniques of Manual Examination, 6th ed., W.B. Saunders Company, Philadelphia, 1995, pp 58-107.

8) 森 於菟 : 筋学. 分担解剖学 1 総説 - 骨学・勒帯学・筋 学, 金原出版, 1994, pp 264-278, pp 309-320, pp 333-345.

9) Rao SS, Bontrager EL, Gronley JK, et al.: Three-dimentional kinematics of wheelchair propulsion. IEEE Trans Rehabil Eng, 1996, 4(3): 152-160.

10) Robertson RN, Boninger ML, Cooper RA, et al.: Pushrim forces and joint kinetics during wheelchair propulsion. Arch Phys Med Rihabil, 1996, 77(9): 856-864.

11) Boninger ML, Cooper RA, Shimada SD, et al.: Shoulder and elbow motion during two speeds of wheelchair propulsion: a description using a local coordinate system. Spinal Cord, 1998, 36(6): 418-426.

12) Masse LC, O'Riain MD: Biomechanical analysis of wheelchair population for various seating positions. J Rehabil Res \& Develp, 1992, 29(3): 12-28.

13) Kornecki S, Zschorlich V: The nature of the stabilizing functions of skeletal muscles. J Biomechanics, 1994, 27(2): 215-225. 